\title{
Projeto "Humanizar-Te" para Estimular a Benevolência no Ấmbito Hospitalar Através do Cuidado a Quem Cuida
}

\author{
Souza, Amanda Gabriela Rocha de \\ Faculdade de Integração do Sertão — aamanda.souza@hotmail.com
}

Introdução "Se todo animal inspira ternura, o que houve então com os homens?". como Guimarães Rosa perguntou há muito tempo, temos nos perguntado cada vez mais nos dias atuais. a desumanidade - falta de humanidade; crueldade - é, no meio do capitalismo, imediatismo, egoísmo e individualismo, a principal das características da sociedade. Diante disso, atualmente tem se falado bastante sobre o resgate do "homem bom" capaz de tratar o outro como gostaria de ser tratado, de respeitar, acolher, confortar e dividir. Dado que no campo da saúde esses problemas surgem num contexto que trata das questões humanas mais profundas, íntimas e que mexem que com nossa vulnerabilidade - vida, morte, tristeza, aflições, medos - este passa a ser então o maior enfoque para implantação/resgate da humanização. É praticamente universal a deficiência (nos mais diversos sentidos) no âmbito hospitalar, sobretudo nos sistemas públicos. no Brasil, a iniciativa para melhoria desse sistema desumano na saúde foi dada pela implantação do Programa Nacional de Humanização da Assistência Hospitalar (PNHAH) seguido da Política Nacional de Humanização (PNH) atuando por meio de diversos dispositivos que promovem mudanças nos modelos de atenção e gestão, dentre eles Grupo de Trabalho de Humanização (GTH). Este abarca um espaço coletivo, organizado e democrático que propõe, além da implantação dos princípios e diretrizes do HumanizaSUS, a troca de saberes e conscientização, entre profissionais de diferentes categorias, gestores e usuários. Objetivos Geral - Implementar o GTH em um hospital regional do sertão pernambucano. Os objetivos específicos são: - Estimular trocas solidárias entre gestores, trabalhadores e usuários para a produção de saúde e a produção de sujeitos. - Humanizar o atendimento aos usuários, se comprometendo com a defesa da vida e fortalecimento do processo de pactuação democrática e coletiva. - Efetivar os princípios do SUS/SUAS no cotidiano das práticas de atenção e de gestão. - Desenvolver pesquisas científicas no campo da humanização, envolvendo profissionais, estudantes, usuários e familiares. Método Trata-se de um projeto de extensão chamado "HumanizAR-TE", desenvolvido por estudantes de fisioterapia e enfermagem que cursaram a disciplina "Humanização em Saúde". para tanto, será implantado o GTH em um hospital regional, inicialmente com profissionais de saúde. As atividades planejadas variam de exercícios físicos à aplicabilidade de recursos lúdicos enquanto proposta pedagógica e terapêutica com o intuito de desenvolver de ações reflexivas e lúdicas no contexto hospitalar, entre outros espaços que perpassem o campo do afeto. Resultados e Discussões por se tratar de um projeto em andamento, até o presente momento foram realizadas duas etapas das cinco propostas. a primeira foi reunir os estudantes que voluntariamente gostariam de participar do projeto. no segundo momento foi firmada a parceria com a instituição e iniciado o planejamento de atividades a serem desenvolvidas.

Souza, Amanda Gabriela Rocha de. Projeto "Humanizar-Te" para Estimular a Benevolência no Âmbito Hospitalar Através do Cuidado a Quem Cuida. In: Anais do Congresso Internacional de Humanidades \& Humanização em Saúde [= Blucher Medical Proceedings, num.2, vol.1]. São Paulo: Editora Blucher, 2014. ISSN 2357-7282

DOI 10.5151/medpro-cihhs-10185 